\title{
Fletcher, Gordon: Dennis Robertson
}

Basingstoke: Palgrave Macmillan, 2008, ix + 256 pp.

本書は, ケインズと同時代のケンブリッジ 学派に属する経済学者デニス・ロバートソン (1890-1963)に関する最新の体系的著作であり， 『経済学における偉大な思想家』(Great Thinkers in Economics）シリーズの 1 冊として刊行され た. 同シリーズは研究者以外の一般の読者も対 象としているため, 文章は平易であり専門用語 についてもわかりやすい読み替えがなされるな どの工夫が行われている．著者のフレッチャー は, 近年ロバートソンの生涯と経済学との関係 について詳細に分析した著著 (Understanding Dennis Robertson: The Man and His Work, Edward Elgar, 2000）を執筆している.

本書は 23 章からなり, ロバートソンの生涯 と主要著作・論文, そしてそれらの相互関係が 詳細に検討されている。以下本書の概略をロ バートソンの生涯に沿って紹介する.

\section{〈人格形成期〉}

彼の幼年期は恵まれていなかった。一家が突 然不運に見舞われた時に生まれ育ったことは， 生涯にわたる貧しさへの恐れを残した。また知 的に秀でていたにもかかわらず，幼年期と青年 期における様々な要因 (絶対的な安心感の欠如, 信仰の喪失, 同性愛的傾向の認識) により失望 と落胆に苛まれていた。

この問題を解決するための方法は次の 2 つで あった. 1 つは様々な人格的側面が調和的な, より心地よい自己へと逃避する方法を探すこと である。もう 1 つは理想化された少年時代とい う架空の黄金時代を回顧し続けることである. ここから導かれるロバートソンの生涯を最もよ く捉えるテーマは,「逃避への願望 (desire for escape)」である.
〈経済学者としての成功〉

ロバートソンにとって逃避は芸術や文学を希 求することを意味したが，その障害となったの は, 父親から受け継いだ深く根ざした義務感で あった．義務と欲求という相反する要求に引き 裂かれ，ロバートソンはその対立を妥協により 解決しょうとした，彼は社会改良のための最良 の手段であり，そして義務を果たそうとする自 己に役立つものとして経済学を専攻した。同時 に彼は, アマチュア俳優としての優れた能力を 最大限に発揮することにより，また自らの著作 を独自の文学的書体で著すことを通じて, 情熱 的で芸術的な本性を満足させようとした。

経済学を選択したことにより，ロバートソン は当時重要な問題となっていた景気循環に関す る研究を行う機会を得て, この領域における第 一級の著作である『産業変動の研究』（1915） を生み出した。この成果を基に師弟関係にあっ たケインズと協力して，貨幣と貯蓄・投資との あるべき関係という当時重要だったマクロ経済 学的問題を考察した. ケインズに強く影響され ながらもロバートソンは先導役となり, 最も革 新的な研究である『銀行政策と価格水準』(1926) が生まれた。

\section{〈ケインズ革命の影響〉}

外見上は求めていた充実した人生を得たよう に思われたが，この妥協の戦略はケインズ革命 へと向かう動きの中で失敗することが運命づけ られていた。 ケインズ革命は古典派（マーシャ ル）経済学を倒し，ロバートソンの経済学者と しての根幹と同時に精神的安定感を徐々に蝕ん でいった，過去を回顧しょうとする気質を持つ ロバートソンにとって, 古典派経済学は自らの 
理論の確固たる基礎であり，これが否定される ことは自身の経済学が否定されることと同義で あった。ケインズ革命が勝利を収めると, 逃避 と義務との妥協案としての経済学の役割は終わ りを迎えた。経済学でこのように大きな打撃を 受けたのは，プロフェッショナルな俳優の世界 への逃避により芸術家という夢を追うことに失 敗した数年後のことだった.

ロバートソンは経済学と芸術とによって不満 足な自己から逃避することに失敗した。逃避が 不可能であることに気付き，ロバートソンはケ インズの影に隠れ生涯を送った。彼は洗練され た論文や著作を書き続け，与えられた賞賛や学 生たちからの敬愛に慰めを見出していた.

以上の叙述は，前書 Understanding Dennis Robertson の内容を基本的には継承しているが, 同書は前半（第 1 部）のロバートソンの性格や 気質を分析するための伝記的記述が半分以上を 占め, 後半（第 2 部）における彼の経済学に関 する記述は, 『産業変動の研究』, 『銀行政策と 価格水準』そしてケインズ革命をめぐる論争が ほとんどを占めていた。ロバートソンの伝記的 記述を重視したフレッチャーの意図としてはや むを得ない構成であったかもしれないが，伝記 的記述から得られた知見と経済学との対応関係 がわかりにくい，またロバートソンの全著作の 一部しか扱われていないという問題があった。

これに対し，本書はロバートソンの理論とそ の背景に関し時系列的な叙述が行われているた め, 彼の「生涯」と「経済学」との関係がより 明確になった。前書では言及されなかった他の 研究, 特にケインズ革命期以降の論文・著作に 関する詳細な記述が加えられたことにより， バートソンの経済学全体を展望することが可能 となった．これが本書の価值を高めている.

またフレッチャーは「偉大な思想家」として のロバートソンの貢献として, 次のような要素 を挙げている.
(1) 経済成長は成長過程における貯蓄を供給 するために，現在の消費を犠牲にすることを要 求する。これが引き起こすのは, 現在生産され ているもののうちどれだけを現在享受し，また まだ生まれていない将来世代の繁栄のために残 すのか, というジレンマである。これに対しロ バートソンは, 現在の経済的厚生の損失を最小 にするように成長を賄う貯蓄を供給すべきであ ると答える。

(2) 過度の好況や深刻な不況を回避しつつ, 経済成長に必要とされる適度の景気循環をもた らすような経済管理が要求される。このとき銀 行は，人々の貯蓄意図を有効にするように物価 水準を調整することになる，貨幣的均衡は，銀 行が一定のルールを順守することにより達成し うるだろう。

(3)このルールを導出する分析の中で， ロ バートソンは貨幣供給の拡張と収縮や銀行によ る産業への資金供給，物価水準の決定，貯蓄の 供給といった諸要素間の関係性に新たな洞察を 加えた. 古典派経済学の枠内であったが, ロバー トソンが引き起こした革新は最終的にケインズ 革命に至る途を用意することになった。 ケイン ズの批判に対し確固とした論陣を張ることがで きたのは，自身のヴィジョンの価值に関するロ バートソンの信念によるものであった.

(4) ロバートソンは貸付資金説やロバートソ ン・ラグ（所得と消費支出とが一定の時間差を 持って現れる関係）など, 現代の経済学にも影 響を与えている諸概念を生み出した.

これらはロバートソンの経済学に関する解釈 として特に新奇なものではないが，本書の最大 の貢献は他の研究領域や一般の読者にもわかり やすい形でこれらを提示したことにある．本書 により, 今後ロバートソンの経済学が幅広く認 知されることを期待したい.

(下平裕之：山形大学人文学部) 